\title{
República e Democracia: Óbvios Ululantes e Não Ululantes
}

\author{
Gosé ORobento Pieina
}

Professor de Direito Tributário da Universidade Federal do Paraná - UFPR e da Faculdade de Direito das Faculdades Integradas Curitiba (Graduação, Especialização, Mestrado e Doutorado), Mestre e Doutor em Direito do Estado - Direito Tributário - PUC/SP, Estudos Pós-

Graduados no Instituto de Estudios Fiscales (Madri, Espanha), Auditor da Receita Federal, Membro Julgador do Conselho de Contribuintes do Ministério da Fazenda - Brasília/DF.

\section{SUMÁRIO}

1 Óbvios ululantes e não ululantes;

2 República e democracia;

3 República;

4 Democracia;

5 Metáforas, prosopopéias e a invisibilidade do óbvio.

\section{1 Óbvios ululantes e não ululantes}

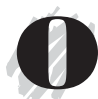

s temas da República e da Democracia estão, indubitavelmente, entre alguns dos mais comuns, correntes, batidos, triviais do nosso Direito Público; sempre e sempre visitados e revisitados, explorados e reexplorados por nossos publicistas. Corremos pois o risco de, ao sobre eles nos debruçarmos, talvez trafegar monotonamente pelo já sabido, quiçá navegar fastidiosamente pelo demasiado conhecido ou até mesmo enveredar enfadonhamente pelo insípido domínio das obviedades.

Óbvio, do latim obvius, ${ }^{1}$ significa aquilo que é claro, manifesto, patente, axiomático, evidente, incontestável; aquilo que não se pode pôr em dúvida, que salta aos olhos, que rebenta à vista, como confirmam

1 CUNHA, Antônio Geraldo da. Dicionário Etimológico Nova Fronteira da Língua Portuguesa. 2. ed., Rio de Janeiro: Nova Fronteira, 1996, p. 556. 
os bons léxicos. ${ }^{2}$ Nesse sentido, tão freqüente é o exame da República e da Democracia pelos nossos juristas, que se pudesse talvez classificá-los como conceitos "óbvios". Quem sabe até estejamos diante de noções tão evidentemente evidentes, tão obviamente óbvias, que caberia ainda maior ênfase. Para esses casos exatamente, a originalidade literária de NELSON RODRIGUES, o admirável teatrólogo e jornalista, cunhou a metáfora do "óbvio ululante". 3

Ululante, do latim ululans, adjetivo derivado do verbo ulular - do latim ululare, que quer dizer ganir, uivar, berrar, bradar, vociferar - significa aquele que berra como animal, que ulula ou uiva como cão ou lobo. Assim, o óbvio ululante é aquele que é claríssimo, gritante, clamoroso, insofismável. ${ }^{4}$

Nítida aqui a criatividade do verbo privilegiado do cronista, particularmente no adjetivar, tão decantado pelos seus apreciadores: "Nelson adjetiva a vida e os homens com uma audácia exemplar" (ARMANDO NOGUEIRA); "Insuperável no adjetivo" (JOSÉ LINO GRÜNEWALD). ${ }^{6}$ Criatividade irrecusavelmente presente também na obra do romancista lusitano JOSÉ MARIA EÇA DE QUEIRÓS, em quem encontramos um notável ponto de contato com NELSON RODRIGUES, pois, no seu O Primo Basílio, de 1878, legou-nos a personagem inesquecível do Conselheiro Acácio, supremo modelo daqueles que cultivam diligentemente o óbvio ululante. ${ }^{?}$

Dessa forma, ao retomarmos tão sovados temas, não estaríamos nós fadados a lavrar tão-somente afirmações acacianas? Não estaríamos nós irremediavelmente condenados ao óbvio ululante? E disso não nos deveríamos vexar? Afinal, em certo momento, o próprio NELSON RODRIGUES declarou: “... envergonha-me estar aqui proclamando o óbvio".

Definitivamente não. Primeiro, porque o ser acaciano é inerente à condição humana; e disse-o também NELSON

2 AULETE, Caldas. Dicionário Contemporâneo da Língua Portuguesa. Vol. IV, 5. ed., Rio de Janeiro: Delta, 1964, p. 2.828; NASCENTES, Antenor. Dicionário da Língua Portuguesa da Academia Brasileira de Letras. Rio de Janeiro: Bloch, 1988, p. 445; HOUAISS, Antônio; VILLAR, Mauro de Salles. Dicionário Houaiss da Língua Portuguesa. Rio de Janeiro: Objetiva, 2001, p. 2.046 .

3 Esse foi o título dado pelo escritor a uma seleção de crônicas, originalmente publicadas como Confissões, nas páginas do jornal O Globo, entre novembro de 1967 e agosto de 1968, como esclarece RUY CASTRO, na introdução a uma reedição dessa obra -RODRIGUES, Nelson. O Óbvio Ululante: Primeiras Confissões (Crônicas), org. Ruy Castro, São Paulo: Companhia das Letras, 1993, (Obras de Nelson Rodrigues, 3), p. 11.

4 CUNHA, Antônio Geraldo da. Dicionário ..., op. cit., p. 802; AULETE, Caldas. Dicionário ..., vol. V, op. cit., p. 4.122; NASCENTES, Antenor. Dicionário ..., op. cit., p. 643; HOUAISS, Antônio; VILLAR, Mauro de Salles. Dicionário ..., op. cit., p. 2.801; FERREIRA, Aurélio Buarque de Holanda. Novo Aurélio Século XXI: O Dicionário da Língua Portuguesa. 3. ed., Rio de Janeiro: Nova Fronteira, 1999, p. 2.026; e FERNANDES, Francisco. Dicionário de Sinônimos e Antônimos da Língua Portuguesa. 38. ed., rev. Celso Pedro Luft, São Paulo: Globo, 1999, p. 842.

5 In RODRIGUES, Nelson. À Sombra das Chuteiras Imortais: Crônicas de Futebol, org. Ruy Castro, São Paulo: Companhia das Letras, 1993, (Obras de Nelson Rodrigues, 4), primeira orelha.

8 Flor de Obsessão. Org. Ruy Castro, São Paulo: Companhia das Letras, 1997, (Obras de Nelson Rodrigues, 12), p. 19. 
RODRIGUES: "Não há ninguém, vivo ou morto, que não faça suas concessões ao Conselheiro Acácio. Impossível nascer, envelhecer ou morrer sem ser acaciano muitas e muitas vezes". ${ }^{9}$ Segundo, porque pomos em dúvida que a reflexão acerca da República e da Democracia necessariamente nos arraste para o óbvio; pois embora assuntos reiterados entre os publicistas, eles são prenhes de minúcias e complexidades que aí estão a justificar a sua renovada consideração. Terceiro, porque, mesmo admitindo, ad argumentandum tantum, que estaremos percorrendo trilhas da obviedade, temos plena convicção de que não será, de modo algum, uma obviedade ululante, mesmo lembrando a igualmente rodriguiana asserção, cujo repensar estamos a propor, de que "Todo óbvio é ululante", 10 uma vez que, mesmo teoricamente já investigados à saciedade absoluta - no que não cremos sempre restará a distância, muitas vezes significativa e mesmo abismal, entre esses princípios e a sua prática no quotidiano de um estado qualquer, inclusive e principalmente do nosso. E aqui sim, numa curiosa inversão de sentido, em virtude da falta flagrante de efetivação desses conceitos tão insistentemente analisados, estamos inegavelmente diante de um óbvio, e de um óbvio inapelavelmente ululante, que clama e reclama por urgente denúncia.
Não se trata aqui de fazer eco à pro cedente reivindicação de FERNANDO SAVATER, o filósofo da Universidade Complutense de Madri: "Hay que cambiar las metáforas anticuadas". ${ }^{11}$ Longe de antiquadas, essas metáforas nunca foram tão adequadas a um tempo quanto a esse que atravessamos, mercê da pobreza filosófica que o invade, da carência de expressão que o assola e da míngua de imaginação que o devasta. Trata-se apenas de sopesar, ponderar e matizar, no plano filosófico, a figura de linguagem rodriguiana, que habita o plano literário - é o óbvio ululante!

\section{República e democracia}

Uma palavra inicial quanto à importância desses temas, essenciais à Política e ao Direito Público, irônica e saborosamente ilustrada por FERNANDO SAVATER, quando nos lembra que os antigos gregos chamavam aos desinteressados na Política de idiotés, significando pessoa isolada, que nada tinha a oferecer aos demais. E completa: "Desse 'idiotés' grego deriva nosso idiota atual, que não preciso explicar o que significa". Parafraseando SAVATER, e de forma até "... um pouco agressiva e irreverente ...", como ele a define, mas perfeitamente lógica e etimológica, diríamos que só não se interessam por esses temas aqueles que se aproximam da idiotice! ${ }^{12}$

9 OÓbvio ..., op. cit., p. 148.

10 Flor ..., op. cit., p. 120.

11 JUAN ARIAS, Fernando Savater: El arte de vivir. México: Planeta, 1998, p. 151-158.

12 Política Para Meu Filho, trad. Eduardo Brandão, São Paulo: Martins Fontes, 1996, p. 16-17. Nessa interessante obra, o autor escreve a seu filho, Amador, então adolescente, explicando-lhe o que é política (no original espanhol: Política para Amador, Barcelona: Ariel, 1992); e que vem, aliás, na esteira de outro trabalho de SAVATER, este ainda mais admirável, fazendo o mesmo com a noção de ética: Ética para meu filho, trad. Monica Stahel, São Paulo: Martins Fontes, 1993 (no original espanhol: Ética para Amador, Barcelona: Ariel, 1991), do qual há reedição recente, acrescida de um apêndice (Ética para Amador, 3. ed., Buenos Aires: Ariel, 2001). 
Embora falando da república, RÉGIS DEBRAY, o professor e filósofo da França, enuncia idéia plenamente aplicável também à democracia: “...nunca se realiza. Seguramente es irrealizable. Todas las repúblicas que existen son esbozos relativos, inferiores a sus principios". ${ }^{13}$ (grifamos) Trata-se de certeza antiga. Já em meados do século XVIII, afirmava JEAN JACQUES ROUSSEAU, aqui se referindo à democracia, mas novamente numa idéia comum a ambas: “... no rigor da acepção, jamais existiu, jamais existirá uma democracia verdadeira”, cuja força o filósofo bem exprime pela hipérbole de reservá-la a uma eventual sociedade divina: "Se existisse um povo de deuses, governar-se-ia democraticamente". ${ }^{14}$ Por isso JUAN RAMÓN CAPELLA, o catedrático de Barcelona, entre outros, observa que “... os processos de democratização são ainda embrionários nas sociedades contemporâneas ...". ${ }^{15}$ Aqui, aliás, presente já a noção de democracia (república também, diríamos) como processo, sublinhada por JOSÉ AFONSO DA SILVA, que revela certa impaciência com a "... tese pessimista, se não de fundo elitista, segundo a qual a democracia nunca fora realizada em sua pureza em lugar algum”, assentando: "Os que assim pensam não concebem que a democracia seja um processo ... Como tal a democracia nunca se realizará inteiramente ...". ${ }^{16}$

Com efeito, república e democracia são noções que indubitavelmente funcionam como "ideais-limites", na expressão confiável de NORBERTO BOBBIO. ${ }^{17} \mathrm{E}$ ideais-limites nitidamente perseguidos pelo movimento jurídico e político dos homens e seus estados, mas num compasso assim descrito, em 1886, por FRIEDRICH NIETZSCHE, cujo verbo filosoficamente profundo e estilisticamente belo era certamente livre, solto e ousado como o de poucos: "... o seu ritmo é demasiado vagaroso e sonolento para os mais impacientes ... atestam os uivos cada vez mais raivosos, o ranger de dentes cada vez mais ostensivo dos cães anarquistas ...".18 Aliás, já em 1878, referindo-se a um sistema político em que o governo fosse um órgão do povo, NIETZSCHE afirmava tratar-se, num vaticínio que o tempo demonstraria demasiado otimista, de um novíssimo conceito que

13 La República explicada a mi hija, trad. Sandra Garzonio, Buenos Aires: Fondo de Cultura Económica, 1999, p. 81. No que tange ao título, preferimos a versão argentina à espanhola - El civismo explicado a mi hija, trad. Manuel Serrat Crespo, Barcelona: Muchnik, 2000 - por uma questão de precisão, que principia pelo título original - La République expliquée à ma fille, Paris: Seuil, 1998 - e encontra definitiva razão de ser no seu conteúdo, que, embora igualmente "cívico", é caracteristicamente "republicano". Trata-se de obra curiosamente semelhante, em sua concepção, às de SAVATER, por último citadas, em que 0 autor explica à sua filha, também adolescente, o que é uma república.

14 "Do Contrato Social ou Princípios do Direito Político". In ROUSSEAU, trad. Lourdes Santos Machado, São Paulo: Abril Cultural, 1973, (Os Pensadores, XXIV), p. 90 e 92.

15 Os Cidadãos Servos, trad. Lédio Rosa de Andrade e Têmis Correia Soares, Porto Alegre: Fabris, 1998, p. 69.

16 Poder Constituinte e Poder Popular (Estudos sobre a Constituição), São Paulo: Malheiros, 2000, p. 45.

17 Igualdade e Liberdade, trad. Carlos Nelson Coutinho, 3. ed., Rio de Janeiro: Ediouro, 1997, p. 8.

18 Além do Bem e do Mal: Prelúdio a uma Filosofia do Futuro, trad. Paulo César de Souza, 2. ed., São Paulo: Companhia das Letras, 2000, p. 102. 
se apoderaria de todas as cabeças, acrescentando, porém: “... para o que, no entanto, talvez necessite de mais um século". ${ }^{19}$

Em termos republicanos e democráticos encontramo-nos também nós, brasileiros, em tenra idade, pois, na palavra inspirada de CÁRMEN LÚCIA ANTUNES RO. CHA, nossa república (e democracia, agregaríamos) foi “... proclamada, conquanto não efetiva, nem definitivamente ... realizada ..."; pior, trata-se de “... uma República ainda muito mal praticada ..."; e pior ainda, confessemos possuir uma "... parca República vivida pelo Brasil”. ${ }^{20}$ Daí sermos arrebatados pela desconfiança de que, entre nós, esses conceitos quiçá não sejam óbvios; e sobretudo, pela certeza de que eles terminantemente não são ululantes. Por outro lado, é precisamente essa pálida e esmaecida vivência republicano-democrática, em face de noções tão obstinadamente pensadas e repensadas, que nos dá certeza de, paradoxalmente, estarmos perante uma obviedade que por certo ulula.

\section{República}

Perante nossa infância republicanodemocrática, nada mais adequado do que olhar para a primeira dessas noções com intuitos minimamente conceptuais. República, do latim res publica, significa "coisa pública", "coisa comum", como esclarece o etimologista (ANTÔNIO GERALDO DA CUNHA) ${ }^{21}$ e confirma o filósofo (RÉGIS DEBRAY), adicionando este: "Es el término genérico que empleaban los antiguos filósofos ... para designar a cualquier 'Estado regido por leyes"”.22 Tal confirmação já é secular, como se vê em ROUSSEAU: "Chamo pois de república todo o Estado regido por leis ..."; que aditava elucidativamente "... pois só nesse caso governa o interesse público e a coisa pública ...". 23 (grifamos) Tamanha a importância da idéia que não admira que EMMANUEL KANT, o velho filósofo de Königsberg, a tenha anunciado como primeiro artigo de um eventual acordo pela paz perpétua: “... a constituição de cada estado deve ser republicana"; ${ }^{24}$ e não admira que FERNANDO SAVATER, o filósofo contemporâneo de Madri, tenha registrado que "... o mínimo que um país no século XX merece é um regime republicano”. ${ }^{25}$

Voltemo-nos para a realidade nacional. Nosso Estatuto Magno não só afirma, logo no primeiro momento do texto, o Princípio da República (art. 1ํ), mas também erige seu núcleo essencial em cláusula imutável (art.

19 Humano, Demasiado Humano: Um Livro para Espíritos Livres, trad. Paulo César de Souza, São Paulo: Companhia das Letras, 2000, p. 243.

20 República e Federação no Brasil: Traços Constitucionais da Organização Política Brasileira, Belo Horizonte: Del Rey, 1997, p. 17, 73 e 85.

21 Dicionário ..., op. cit., p. 677.

22 La República, op. cit., p. 19.

23 Do Contrato Social ..., op. cit., p. 61.

24 Apud BOBBIO, Norberto. O Futuro da Democracia: uma defesa das regras do jogo. Trad. Marco Aurélio Nogueira, 3. ed., Rio de Janeiro: Paz e Terra, 1986, p. 38.

25 Política..., op. cit., p. 199. 
60, § 4ํㅗ II), apenando sua inobservância com a severidade da intervenção federal nos estados (art. 34, VII, a).

Conquanto a doutrina constitucional brasileira, após o advento do texto de 1988, numa lamentável tendência literal, incline-se no sentido de que a República não mais constitui cláusula intocável, é evidente que, vencida, em 21 de abril de 1993, a possibilidade de revisão constitucional a respeito (art. 2ㅇ do Ato das Disposições Constitucionais Transitórias), a sua idéia nuclear de representação (voto direto, secreto e universal - art. $60, \S 4$ o , II) segue presente, assim como a de temporariedade (voto periódico - art. 60, $\S 4$ ํㅡ, II), e até mesmo a de igualdade, para aqueles que a entendem integrante da noção republicana (entre os direitos individuais - art. 60, $\S$ $4^{\underline{o}}$, IV). Donde crermos que, se a razão não se encontra com GERALDO ATALIBA ("O Autor entende que o princípio republicano, muito embora não expresso diretamente ... foi mantido na Constituição de 1988 como 'cláusula pétrea' [dependente apenas do resultado do plebiscito], eis que está ele consagrado nos demais princípios estabelecidos no $§ 4^{\mathrm{o}}$ do art. 60 ..."), ${ }^{26}$ certamente encontrar-se-á com PINTO FERREIRA ("A essência da república está no voto direto, secreto, universal e periódico ..."). ${ }^{27}$ Para CÁRMEM LÚCIA
ANTUNES ROCHA, cuja posição se nos afigura sensata, entre a promulgação constitucional e o plebiscito de 1993, a república não foi cláusula pétrea, pela possibilidade de sua modificação pela via revisional, após o quê, recobrou sua condição de imodificável, como limite material implícito. ${ }^{28}$ ROQUE ANTONIO CARRAZZA prefere ver, no dispositivo constitucional, a petrificação dos reflexos republicanos. ${ }^{29}$

É este “... o princípio mais importante e decisivo do nosso direito público”, “... a síntese de todas as nossas instituições", na apreciação de GERALDO ATALIBA, insuperável na acuidade com que mergulhou em todos os meandros e escaninhos da complexa noção. ${ }^{30}$

Define-o a pena do mestre como "... o regime político em que os exercentes de funções políticas (executivas e legislativas) representam o povo e decidem em seu nome, fazendo-o com responsabilidade, eletivamente e mediante mandatos renováveis periodicamente". Não obstante pôr friso na idéia de igualdade, não é discrepante a visão de ROQUE ANTONIO CARRAZZA, para quem "República é o tipo de governo, fundado na igualdade formal das pessoas, em que os detentores do poder político exercem-no em caráter eletivo, representativo (de regra), transitório e com responsabilidade". ${ }^{31}$

26 República e Constituição, atualiz. Rosolea Miranda Folgosi, 2. ed., São Paulo: Malheiros, 1998, p. 39, n.a. 1.

27 Comentários à Constituição Brasileira, vol. 3, São Paulo: Saraiva, 1992, p. 212.

28 República e Federação ..., op. cit., p. 70, 86 e 88-89.

29 Curso de Direito Constitucional Tributário, 16. ed., São Paulo: Malheiros, 2001, p. 68-70.

30 República e Constituição, São Paulo: RT, 1985, p. XI e XIV; na segunda edição, op. cit:: p. 15 e 18.

31 ATALIBA, Geraldo. Ibidem, p. IX; na edição atualizada, ibidem: p. 13. CARRAZZA, Roque Antonio. Curso ..., op. cit., p. 40. 
Dessarte, pode-se inferir que caracterizam a República: a representatividade, decorrente da eletividade, a transitoriedade e a responsabilidade. Traços entre os quais cumpre conceder relevo ao primeiro deles, pois a República é, antes e acima de tudo, aquele regime de governo em que as autoridades são meros administradores da coisa pública - res publica - a título de mandatários do povo, que detém a sua propriedade.

Daí assistir integral razão a GERALDO ATALIBA quando coloca a idéia de mandato como "Pedra de toque do sistema ... ponto de referência dos demais institutos informadores da República ...", localizando-o "... no centro de toda construção jurídica da República". 32

Os poderes atribuídos aos mandatários do povo só descobrem sentido na idéia de função, na idéia de meios para a realização do interesse público. A ênfase em tais poderes, marco de uma época que já deixamos para trás, deve ceder espaço ao acento posto nos seus deveres em relação às finalidades consagradas na lei. Somente para cumpri-los e para atingi-las é que se lhes outorgam poderes. Daí a inclinação de mui- tos autores modernos, recorda MARCELO CAETANO, denominando-os poderes-deveres, nomenclatura que ganhou divulgação a partir de SANTI ROMANO, como lembra CELSO ANTÔNIO BANDEIRA DE MELLO. ${ }^{33}$ Nenhum, porém, meditando à luz da noção funcional, logrou projetar tão longe suas conseqüências, como o fez CELSO ANTÔNIO, chegando a propor uma inversão do binômio: deveres-poderes mais do que poderes-deveres. ${ }^{34}$ Não obstante a questionabilidade dessas expressões híbridas perante a Lógica Jurídica, ${ }^{35}$ é forçoso reconhecer a irrecusável coerência da proposta desse eminente publicista, uma vez que os poderes não passam de simples instrumentos conferidos ao administrador público, de sorte a equipá-lo na incessante procura do atender às finalidades legais. Aí seus deveres inafastáveis.

Este é o momento e o local para aduzirmos ao tema a teoria da Relação de Administração, que, a despeito de formulada no âmbito do Direito Administrativo, exprime com precisão a representatividade republicana, opondo o dono da coisa pública (o povo) ao seu administrador (gover-

32 Ibidem, p. 64-65; na edição atualizada, ibidem: p. 90-91.

33 CAETANO, Marcelo. Princípios Fundamentais do Direito Administrativo. Rio de Janeiro: Forense, 1977, p. 141. MELLO, Celso Antônio Bandeira de. Elementos de Direito Administrativo. 2. ed., São Paulo: RT, 1990, p. 53; e Curso de Direito Administrativo. 12. ed., São Paulo: Malheiros, 2000, p. 69.

34 "Controle Judicial dos Atos Administrativos". In Revista de Direito Público no 65, São Paulo: RT, jan.-mar./1983, p. 31; Princípios Fundamentais de Direito Administrativo, in CELSO ANTÔNIO BANDEIRA DE MELLO (coord.), Curso de Direito Administrativo, São Paulo: RT, 1986, p. 22; "Legalidade, Motivo e Motivação do Ato Administrativo". In Revista de Direito Público n- 90, São Paulo: RT, abr.jun./1989, p. 60; Elementos ..., op. cit., p. 23 e 52-55; e Curso ..., op. cit., p. 32 e 68-70.

35 São questionáveis, perante a Lógica Jurídica, essas expressões, poderes-deveres ou deveres-poderes, uma vez que, nas normas jurídicas, ocorre a tripartição do universo da conduta nos chamados modais deônticos, obrigatório, permitido e proibido, na lição de LOURIVAL VILANOVA (Lógica Jurídica, São Paulo: Bushatsky, 1976, p. 124-126; As Estruturas Lógicas e o Sistema do Direito Positivo, São Paulo: RT e EDUC, 1977, p. 37-38). Em verdade, cremos que, na versão tradicional (poderes-deveres), concede-se destaque ao primeiro membro do binômio, e estamos em presença do modal permitido; enquanto na versão mais recente (deveres-poderes), o friso posto nos deveres revela o modal obrigatório. 
nante, representante, mandatário).${ }^{36}$ Essa teorização foi virtuosamente urdida e composta por aquele que os mestres apresentam como seu mestre. Não é prudente mais do que transcrever com respeito as asserções geniais que faz, ao opor as idéias de propriedade e de administração, esta típica do Direito Público, aquela característica do Direito Privado, o grande RUY CIRNE LIMA, jurista dos pampas e do Brasil, para o nosso justo orgulho:

"A palavra administração ... designa geralmente a atividade do que não é proprietário - do que não é senhor absoluto ... Administração, segundo o nosso modo de ver, é a atividade ... do que não tem a disposição da cousa ou do negócio administrado ... Na administração, o dever e a finalidade são predominantes; no domínio, a vontade ... O fim, - e não a vontade, domina tôdas as formas de administração ... Supõe, destarte, a atividade administrativa a preexistência de uma regra jurídica, reconhecendo-lhe uma finalidade própria ... À relação jurídica que se estrutura ao influxo de uma finalidade cogente, chama-se relação de administração ..."37 (sic) (grifamos)

Em lugar de nossa avaliação pessoal, de pouco significado, lançamos mão das palavras daquele publicista que, com tanto brilho, versou o tema da República, e cujo depoimento acerca da Relação de Admi- nistração, tal como vista por CIRNE LIMA, é dos mais expressivos: "Na verdade, a idéia de representação e o instituto do mandato, como fulcros da concepção republicano-democrática-do ponto de vista jurídico - explicam-se pela relação de administração, que entre nós encontrou seu expositor máximo em RUY CIRNE LIMA ...".38 (grifamos) (GERALDO ATALIBA)

\section{Democracia}

Apertemos agora o olhar para a idéia de representação, ainda navegando em águas republicanas, e no centro delas, mas já lhes reconhecendo aqui o influxo da correnteza democrática.

A aproximação entre as noções de República e de Democracia data dos antigos, como se pode ver em CÍCERO (NICOLLA MATTEUCCI e CÁRMEN LÚCIA ANTUNES ROCHA).${ }^{39}$ Considere-se, por exemplo, do século XVIII, a referência de JAMES MADISON, nos célebres comentários à constituição norte-americana - $\mathrm{O}$ Federalista: "... la confusión de los conceptos de república y democracia ...". ${ }^{40}$ E considerese também, dos nossos dias, a conclusão de CÁRMEN LÚCIA ANTUNES ROCHA, voltada para o nosso caso: "Os princípios republicano e democrático modelam-se e condicionam-se reciprocamente ... Os dois

36 ATALIBA, Geraldo. República ..., op. cit., p. 64 e 68; na edição atualizada, op. cit.: p. 90 e 94.

37 Princípios de Direito Administrativo. 6. ed., São Paulo: RT, 1987, p. 20, 22, 52, 22 e 51.

38 República ..., op. cit., p. 64; na edição atualizada, op. cit.: p. 90.

39 MATTEUCCI, Nicola. República. In NORBERTO BOBBIO, NICOLA MATTEUCCI e GIANFRANCO PASQUINO, Dicionário de Política, 3. ed., vol. 2, trad. Carmen C. Varrialle et al., Brasília: UnB e Linha Gráfica, 1991, p. 1.107 e 1.108. ROCHA, Cármen Lúcia Antunes. República ..., op. cit., p. 22.

40 El Federalista - XIV. In ALEXANDER HAMILTON, JAMES MADISON e JOHN JAY, El Federalista, México: Fondo de Cultura Económica, 2000, p. 53. 
princípios estão fundidos e condenados a serem tomados como uma expressão única e indissociável enquanto vigorar o atual sistema: República Democrática”. ${ }^{41}$

Antes de nos debruçarmos sobre a segunda dessas noções, registremos que, a exemplo do que ocorreu com a filosofia, como já tivemos oportunidade de consignar, também a democracia constitui uma invenção dos gregos. ${ }^{42}$ FERNANDO SAVATER recorre a um episódio da Guerra de Tróia, quando Aquiles, o grande guerreiro grego, afasta-se dos combates, por zangar-se com Agamenon, que chefiava o famoso cerco, como rei e cunhado da bela Helena, a quem os gregos buscavam recuperar dos troianos. Estabelecida a discussão entre os chefes aqueus, com a participação de Ulisses, para acolher a decisão da maioria; assinala SAVATER que, nessa passagem da Ilíada, “... o que no fundo Homero está contando são os albores da democracia ....". ${ }^{43}$ Nada mais do que uma experiência incipiente e muito restrita, a dos gregos, pois, entre eles, ficavam de fora das decisões as mulheres, os escravos e os estrangeiros residentes, anota o autor em outra obra: "Lo cual en nada disminuye la importancia radical, incomparable, del primer paso"; ${ }^{44}$ que exigiu nada menos que uma "... certa loucura ..." - "Felizmente, os gregos eram meio loucos e de sua genial loucura ainda agora nos alimentamos". ${ }^{45}$

Curioso que, seja qual for o posicionamento ou matiz ideológico, dentro do mais largo espectro imaginável, todos, sem exceção, tendem hoje a proclamar-se democráticos. E não raro, diante do seu estranho fascínio (IGNACIO DA SILVA TELLES), ${ }^{46}$ “... se entredevoram pela democracia”, como depõe MANOEL GONÇALVES FERREIRA FILHO. ${ }^{47}$ Tão elevado é o grau de polissemia do termo, como confirmam LOURIVAL VILANOVA e MISABEL DE ABREU MACHADO DERZI; ${ }^{48}$ a ponto de LUÍS ALBERTO WARAT dizê-lo contaminado por uma "anemia significativa"49 ou "anemia semântica". 50

Mais do que nunca, pois, abre-se espaço para o "processo de elucidação" que pregava RUDOLF CARNAP, integrante do

41 República ..., op. cit., p. 69.

42 Quanto à precedência grega na filosofia, invocamos, para defendê-la, as reflexões insuspeitas de FRIEDRICH NIETZSCHE, de GUILLERMO FRAILE e de MARILENA CHAUÍ - "A Noção de Sistema no Direito". In Revista da Faculdade de Direito da UFPR, Porto Alegre: Síntese, ํㅜ 33, 2000, p. 55.

43 Política ..., op. cit., p. 71-73.

44 Diccionario Filosófico. México: Planeta, 1999, p. 80-81.

45 Política..., op. cit., p. 74-84.

46 A Experiência da Democracia Liberal. São Paulo: RT, 1977, p. 75.

47 Curso de Direito Constitucional. 17. ed., São Paulo: Saraiva, 1989, p. 84.

48 VILANOVA, Lourival. Novo Poder Executivo para o Brasil. In AURÉLIO WANDER BASTOS et al., Uma Nova Organização Político-Constitucional para o Brasil de Hoje, Fortaleza: UFC, 1982, p. 115. DERZI, Misabel. "Nota de Atualização no 2 ao art. 96". In ALIOMAR BALEEIRO, Direito Tributário Brasileiro, 11. ed., Rio de Janeiro: Forense, 1999, p. 610.

49 Apud STRECK, Lenio Luiz; MORAIS, José Luiz Bolzan de. Ciência Política e Teoria Geral do Estado. Porto Alegre: Livraria do Advogado, 2000, p. 97.

50 Apud SANTI, Eurico Marcos Diniz de. Decadência e Prescrição no Direito Tributário. São Paulo: Max Limonad, 2000, p. 71. 
Círculo de Viena e ex-professor da Universidade de Chicago. ${ }^{51}$ Processo em que, numa primeira etapa, surpreendemos, na origem grega de democracia, o significado etimológico de governo ou poder do povo; ${ }^{52}$ confirmado pela investigação filosófico-política do século XX, desde HANS KELSEN $^{53}$ até RÉGIS DEBRAY e JUAN RAMÓN CAPELLA. ${ }^{54}$ Um passo adiante, NORBERTO BOBBIO aponta-a como a forma de governo em que “... o poder não está nas mãos de um só ou de poucos, mas de todos, ou melhor, da maior parte ... da maioria ...". 55

No que diz respeito à evolução histórica desse conceito, fiquemos com este mesmo eminente teórico geral do direito e filósofo político italiano, que distingue a democracia dos antigos (direta) da democracia dos modernos (representativa) $;{ }^{56}$ no que é seguido por vasta doutrina, da qual citamos, exemplificativamente, FRANCISCO RUBIO LLORENTE, o constitucionalista da Universidade Complutense de Madri. ${ }^{57}$ Pouco diversa é a visão de MANOEL GONÇALVES FERREIRA FILHO, que aponta três fases diversas: Democracia Antiga (direta), Democracia Moderna (representativa) e Democracia Contemporânea (participativa), fase esta última para a qual o constitucionalista do Largo São Francisco prefere a denominação de Poliarquia, no sentido de "o governo de muitos", acatando sugestão de ROBERT DAHL. ${ }^{58}$

Em face, contudo, dos limites estreitos do presente trabalho, contentemo-nos com a identificação do mínimo semântico da voz Democracia. E o fazemos, uma vez mais, em honrosa companhia: “... forma pela qual o poder (cuja suprema manifestação está em fazer leis) é exercido pelo povo ou por seus representantes eleitos" (MISABEL DERZI); “... democracia existirá ... ali onde a vontade estatal ... contenha mediata ou imediatamente a participação do povo" (LOURIVAL VILANOVA). ${ }^{59}$

Ora, é no procedimento legislativo, nos atos da produção legislativa que, indiscutivelmente, se surpreende a realização por excelência dessa dimensão participativa popular. Eis que, nessa porção mínima da noção conceptual de Democracia, identifica-se uma

51 Apud WARAT, Luis Alberto. O Direito e Sua Linguagem. Porto Alegre: Fabris, 1984, p. 57.

52 CUNHA, Antônio Geraldo da. Dicionário ..., op. cit., p. 246 e 224-225.

53 A Democracia, trad. Ivone Castilho Benedetti et al., São Paulo: Martins Fontes, 1993, p. 140; Escritos sobre la Democracia y el Socialismo, trad. Juan Ruiz Manero et al., Madrid: Debate, 1988, p. 208.

54 DEBRAY, Régis. La República ..., op. cit., p. 19. CAPELLA, Juan Ramón. Os Cidadãos ..., op. cit., p. 68; que cogita de “... autogoverno das populações pelas populações mesmas ...".

55 Liberalismo e Democracia, trad. Marco Aurélio Nogueira, 3. ed., São Paulo: Brasiliense, 1990, p. 7 e 31.

56 Ibidem, p. 31-36.

57 Estado e Democracia na Construção da Europa, trad. Fernando Aurelio Zilveti e Ana Marta C. de Barros Zilveti, in SÉRGIO RESENDE DE BARROS e FERNANDO AURELIO ZILVETI (coord.), Direito Constitucional: Estudos em Homenagem a Manoel Gonçalves Ferreira Filho, São Paulo: Dialética, 1999, p. 127.

58 A Democracia no Limiar do Século XXI, São Paulo: Saraiva, 2001, p. 1-36.

59 DERZI, Misabel. "Nota de Atualização no 2 ao art. 96". In Direito ..., op. cit., p. 611; VILANOVA, Lourival. Novo Poder ..., op. cit., p. 113-114. 
indefectível conexão com o Princípio da Legalidade; e evidente que, se não o bastante para o desabrochar democrático em sua plenitude, mais do que o suficiente para reconhecer-lhe uma manifestação efetivamente substancial.

Afinal, entre as decisões democráticas cuja tomada cabe originariamente ao povo, via representação política, ergue-se magnífica e soberana a decisão primordial da elaboração legislativa, nas palavras de SAVATER, “... antes privilegio inamovible de los dioses o capricho indiscutible de los tiranos"; consubstanciadora da autonomia política pela qual se recusam inapelavelmente todas as leis cuja promulgação não advenha dos representantes legitimamente habilitados. ${ }^{60}$ Com efeito, como proclamou VICTOR HUGO, o literato de Os Miseráveis, Quem vota reina! ${ }^{61}$

E complete-se a referência a essa noção mínima de Democracia invocando, de conformidade com as lições kelsenianas, o princípio da maioria na determinação da ordem social. Trata-se, no dizer de $\mathrm{BOBBIO}$, de "... regra fundamental da democracia ...”. ${ }^{62}$ Entretanto, regra majoritária que convive com o direito da minoria: "A maioria pressupõe ... a existência de uma minoria ... Se a minoria não for eliminada do procedimento no qual é criada a ordem social, sempre existe uma possibilidade de que a minoria influencie a vontade da maioria" (HANS KELSEN). ${ }^{63}$ Direito da minoria este que deve seguir inatacável e intocável, sob pena de inconsistência democrática, porque a regra majoritária sozinha não faz democracia: "Las decisiones democráticas son mayoritarias, pero no toda decisión mayoritaria es democrática. Ninguna mayoría tiene derecho democrático a votar a favor de la sumisión sin derechos de las minorías ..." (FERNANDO SAVATER); 64 "La democracia no es el reino de la mayoría. Hay democracia cuando la minoría conserva sus derechos de expresión y de organización" (RÉGIS DEBRAY). ${ }^{65}$

Sem enveredar pelo aprofundamento do conceito democrático, tarefa que extravasaria as nossas, no particular, pouco ambiciosas fronteiras, limitemo-nos ao registro da convicção que partilhamos com MISABEL DERZI, no sentido de que a democracia, que o legislador da Carta de 1988 nela consagrou, vai além desse miolo significativo mínimo, ultrapassando a legalidade formal, e firmando compromisso de ordem material com a liberdade e a igualdade. ${ }^{66}$ Cogita-se aqui da realização mais radical desses valores - fundamentos irrecusáveis da democracia (NORBERTO $\mathrm{BOBBIO})^{67}$ - de forma a transcender a

60 Diccionario ..., op. cit., p. 80 e 89.

61 No original francês: "Qui vote règne" - Apud CAPELLA, Juan Ramón. Os Cidadãos ..., op. cit., nota n 184, p. 135.

62 O Futuro ..., op. cit., p. 19.

63 Teoria Geral do Direito e do Estado, trad. Luís Carlos Borges, São Paulo e Brasília: Martins Fontes e UnB, 1990, p. 280-281.

64 Diccionario ..., op. cit., p. 95; e Política ..., op. cit., p. 183.

65 La República ..., op. cit., p. 23.

66 "Nota de Atualização no 2 ao art. 96". In Direito ..., op. cit., p. 611.

67 Igualdade e Liberdade, op. cit., p. 8. 
mera liberdade assegurada pela igual participação na gestão pública, mediante, principalmente, o exercício da liberdade da igual participação nas decisões legislativas; para galgar patamar substancialmente superior, em que a todos seja assegurada a possibilidade de realização de suas capacidades, através de uma efetiva igualdade de oportunidades, de modo que a ninguém seja recusado o exercício de sua cidadania por força das amarras econômicas que o mantenham refém de suas necessidades vitais básicas. ${ }^{68}$

Ponhamos friso, ainda, em uma idéia que já sobressai nesse mínimo essencial da democracia, valendo-nos da voz privilegiada de OCTAVIO PAZ, o soberbo escritor mexicano, Prêmio Nobel de Literatura de 1990, para quem “... la democracia ... es un método de convivencia civilizada ... pide que cada uno sea capaz de convivir com su vecino, que la minoría acepte la voluntad de la mayoría, que la mayoría respete a la minoría y que todos preserven y defiendan los derechos de los individuos". ${ }^{69}$ (grifamos) De fato, democrático é, sem dúvida, o convívio pacífico das discordâncias e a convivência serena das divergências. Não por outra razão, MARILENA CHAUÍ apresenta a democracia como "... a única sociedade e o único regime político que considera o conflito legítimo"; 70 e diverso não calharia ser, porque o conflito é intimamente próprio do humano.
Ao fim do segmento, a sábia eloqüência do filósofo espanhol do vitalismo, que encontra um índice seguro de vida civilizada já nessa noção menor de democracia, tão admirável que lhe parece beirar a incompreensão. Com a palavra ORTEGA Y GASSET:

"Civilização é, antes de tudo, vontade de convivência. É-se incivil e bárbaro na medida em que não se conte com os demais. A barbárie é tendência à dissociação ...

A forma que na política representou a mais alta vontade de convivência é a democracia liberal ... o Poder público, não obstante ser onipotente, limitase a sí mesmo e procura, ainda a sua custa, deixar espaço no Estado que êle impera para que possam viver os que nem pensam nem sentem como êle, quer dizer, como os mais fortes, como a maioria ... é a suprema generosidade: é o direito que a maioria outorga à minoria e é, portanto, o mais nobre grito que soou no planêta. Proclama a decisão de conviver com o inimigo; mais ainda, com o inimigo débil. Era inverossímil que a espécie humana houvesse chegado a uma coisa tão bonita, tão paradoxal, tão elegante, tão acrobática ...

Conviver com o inimigo! Governar com a oposição! Não começa a ser já incompreensível semelhante ternura? (sic) ${ }^{71}$

68 SAVATER, Fernando. Diccionario ..., op. cit., p. 86-91; DEBRAY, Régis. La República ..., op. cit., p. 78.

69 Apud SAVATER, Fernando. Diccionario ..., op. cit., p. 94.

70 Convite à Filosofia, 4. ed., São Paulo: Ática, 1995, p. 433.

71 A Rebelião das Massas, trad. Herrera Filho, Rio de Janeiro: Ibero-Americano, 1959, p. 120-121. 


\section{Metáforas, prosopopéias e a invisibilidade do óbvio}

Ninguém põe em dúvida a enorme relevância da linguagem para o homem e para o mundo, inclusive para o Direito. Quando São João inicia seu evangelho, registra, numa clara alusão ao Gênesis: "No princípio era o Verbo, e o Verbo estava com Deus, e o Verbo era Deus" (Jo. 1, 1). O evangelista ilustra aí vigorosamente o poder da palavra, não só realçando a “... força ..." e a “... onipresença da linguagem", como assinala GABRIEL CHALITA, ${ }^{72}$ mas além, destacando que "... el Verbo pone en orden el caos ...", que "... la regulación de las cosas sólo se realiza en y con la palabra", como adverte RAÚL CARRANCÁ Y RIVAS, jurista e filósofo do direito mexicano. ${ }^{73}$

Ao preparar-nos para empreender nossas considerações acerca da República e da Democracia, começamos por invocar metáforas confluentes como a do Conselheiro Acácio e seus truísmos (de EÇA DE QUEIRÓS) e principalmente a do óbvio ululante (de NELSON RODRIGUES). No que diz respeito ao recurso a essas figuras de linguagem, façamos dois esclarecimentos. Primeiro, que cogitamos de metáfora no sentido amplo de "... uma comparação abreviada ...", sem distinguir entre os diversos grupos de figuras de linguagem (HÉLIO DE SEIXAS GUIMARÃES e ANA
CECÍLIA LESSA). ${ }^{74}$ Segundo, que, descendo às especificidades, estaríamos, por exemplo, no caso do óbvio ululante, diante de uma figura de pensamento do tipo Prosopopéia, “... que consiste no emprestar vida aos seres inanimados, fictícios, ausentes ou mortos" (SEBASTIÃO CHERUBIM) ${ }^{75}$ ou "... em pensar seres inanimados ou irracionais como se eles fossem humanos (ou animais), atribuindo-lhes linguagem, sentimentos e ações típicos dos seres humanos (ou dos animais)" (adicionamos, entre parênteses) (HÉLIO DE SEIXAS GUIMARÃES e ANA CECÍLIA LESSA) ${ }^{76} \mathrm{O}$ "óbvio" é o ser inanimado ao qual se atribui vida, linguagem, ações, na prosopopéia em tela, mais especificamente, se atribui a capacidade de ulular ou uivar.

Sabemos que na linguagem estritamente científica, como a da Ciência do Direito, impera a lógica clássica (alética ou apofântica), enquanto na linguagem metafórica reina aquela que os especialistas em linguagem denominam de "... lógica da sensibilidade" (HÉLIO DE SEIXAS GUIMARÃES e ANA CECÍLIA LESSA). ${ }^{77}$ Lógica esta para a qual apelamos, ao invocar metáforas e prosopopéias, na tentativa de responder convenientemente ao que FERNANDO SAVATER chama de "La exigencia de avivar la imaginación adormecida ...", ${ }^{78}$ necessidade tão maior no âmbito

72 A Sedução do Discurso: O Poder da Linguagem nos Tribunais do Júri, São Paulo: Max Limonad, 1998, p. 68.

73 El Derecho y la Palabra (Ius Semper Loquitur), México: Porrúa, 1998, p. 1.

74 Figuras de Linguagem: Teoria e Prática, São Paulo: Atual, 1988, p. 9.

75 Dicionário de Figuras de Linguagem, São Paulo: Pioneira, 1989, p. 55.

76 Figuras ..., op. cit., p. 54.

77 Ibidem, p. 15.

78 Despierta y lee, 4. ed., Madrid: Alfaguara, 1998, p. 78. 
jurídico quanto mais hermético e profundo é o sono que enclausura e mantém cativos os operadores do direito, reconhecidamente dados e afeitos aos formalismos e academicismos, com freqüência ocos e vazios, precisamente do tipo dos do Conselheiro Acácio de EÇA. Afinal, o dilema que nos apresenta SAVATER é radical e inquietante: "Imaginación o barbarie". 79

Se no momento primeiro deste texto, considerando que República e Democracia são conceitos tão assiduamente versados pela doutrina publicista, cogitamos de talvez encará-los como óbvios, embora pondo em dúvida tal condição, não nos incomoda ao fim admitir, só para argumentar, essa obviedade; desde que não se lhe adjetive de "ululante", compondo a imagem rodriguiana completa. E isso porque, se no patamar exclusivamente da teoria pode-se tolerar a eventual conotação de evidência dessas noções, tal não se dá, com clareza resplandecente e fulgurante, no nível da prática, pois o modo pelo qual elas se concretizam na experiência dos estados contemporâneos, especialmente na nossa particular, fica a incomensuráveis distâncias da elevada altitude de suas especulações abstratas. Afastamento teórico-prático que, num giro inverso, constitui, este sim, inevitável óbvio, a reclamar urgente acusação. Em outras palavras, mesmo que não sejam óbvios os conceitos, e muito menos ululantes, de inegável obviedade, até mesmo ululante, é o desleixo na sua concretização, a negligência na sua materialização, a escas- sez da sua execução, a ausência de sua realização.

Voltemos uma vez mais a NELSON RODRIGUES, para atentar para o sonho curioso que ele descreve:

"Sonhei que Deus chegava perto de mim e perguntava: - 'O que é que você fez na vida?'. Tratei de vasculhar todas as províncias do meu passado ... E a verdade, a lamentável verdade, é que eu não encontrava, em toda a minha biografia, nada que surpreendesse o Altíssimo e merecesse o Seu espanto. Eis senão quando, de repente, baixa em mim uma luz genial. Alço a fronte e digo: 'Eu promovi, eu consagrei o óbvio!'. Aí está o grande feito de toda a minha vida ... arranquei-o da obscuridade, da insignificância. Hoje, o óbvio tem trânsito em todas as áreas ..."10 (grifamos)

Com efeito, o apontar imaginativamente o óbvio pode verdadeiramente constituir a realização e a tarefa de toda uma vida, como a do inspirado escritor, enchendo-a e preenchendo-a, recheando-a e saturando-a à mais completa integralidade, à mais acabada inteireza, à mais absoluta plenitude!

Por isso se trata de missão superior, assim explicitada pelo mesmo sublime cronista: "Muitas vezes esbarramos, tropeçamos no óbvio. Pedimos desculpas e passamos adiante, sem desconfiar de que o óbvio é o óbvio. Só o profeta, com sua espantosa vidência, olha o óbvio e diz: - 'Ali está o óbvio'... Toda a história humana ensina que só os profetas enxergam o óbvio". ${ }^{81}$ (grifamos)

79 Ibidem, p. 75.

80 Flor ..., op. cit., p. 121.

81 Ibidem, p. 120. 
O profeta, a quem cabe descortinar e revelar imaginosamente o óbvio, é aquele que, numa evolução gradual do semanticamente pobre e indigente para o rico e opulento, significa: primeiro, "indivíduo que prediz o futuro" (ANTÔNIO GERALDO DA CUNHA); ${ }^{82}$ segundo, "... aquele que fala em nome de ..." Deus ou da verdade (HUGO SCHLESINGER e HUMBERTO PORTO, e CARLOS MESTERS); ${ }^{83}$ terceiro e último, profetas são aqueles que "... criticam comportamentos e estruturas ..." (CARLOS MESTERS), ${ }^{84}$ aqueles que exercem por inteiro "... o falar com soberania e coragem, dizer a verdade sem compromissos, anunciar e denunciar mesmo correndo riscos de ordem pessoal" (LEONARDO BOFF).$^{85}$

Profeta é aquele que, identificando e diagnosticando com imaginação os óbvios, tais como os conceitos mínimos essenciais de República e Democracia, e tais como o escandaloso intervalo que os afasta e aparta de sua prática no quotidiano da vida pública, aqui além de óbvio também ululante, assume consciente e conseqüente a missão da denúncia; no verbo magnífico de
FRIEDRICH NIETZSCHE, o comportamento do homem do amanhã, "... em contradição com o seu hoje ...", autêntico ponto de interrogação, titular de tarefa "... dura, indesejada, inescapável ...”, mas sobretudo grande, na medida em que lhe cabe agir como "consciência do seu tempo". ${ }^{86}$ No que tange à República e à Democracia, é a tarefa que RUY BARBOSA e GERALDO ATALIBA, ontem, e tantos outros, hoje, com superna estatura intelectual e dignidade jurídica de excelência, levaram e levam a cabo em seu tempo, lugar e circunstância.

E todo o desmedido impedimento que perturba e obsta o sucesso da missão profética de denúncia imaginativa do óbvio, todo o desmesurado óbice, todo o imenso embaraço, todo o colossal estorvo, reside simplesmente naquilo que o mesmo NELSON RODRIGUES, noutro rasgo de genialidade filosófico-literária, precisamente classificou como A Invisibilidade do Óbvio! ${ }^{87}$

Itapoá/SC, 30 de março de 2002 Dia de São João Clímaco.

82 Dicionário Etimológico ..., op. cit., p. 637.

83 SCHLESINGER, Hugo; PORTO, Humberto. As Religiões Ontem e Hoje. São Paulo: Paulinas, 1982, p. 217. MESTERS, Carlos. Deus, Onde Estás? 5. ed., Belo Horizonte: Veja, 1976, p. 48.

84 Ibidem, p. 58.

85 E a lgreja se fez Povo - Eclesiogênese: a Igreja que nasce da fé do povo, São Paulo: Círculo do Livro, 1986, p. 216.

86 Além do Bem ..., op. cit., p. 118-119.

87 À Sombra ..., op. cit., p. 135-136. 